TURIZAM

Volume 22, Issue 2

42-51 (2018)

ORIGINAL

SCIENTIFIC PAPER

\title{
Comparison and the Effectiveness of Tourism Policies between Macedonia and Serbia
}

\author{
Dejan Galovski ${ }^{\mathrm{A}}$ \\ Received: January 2018 | Accepted: February 2018 \\ DOI: $10.5937 / 22-17526$
}

\begin{abstract}
Tourism is one of the most growing industries and engine of the national economies. In the recent years, every tourist destination and countries as a one tourist destination implement many marketing policy and strategies to promote and developed their national tourism products. In this paper will compare Macedonian and Serbian tourism marketing policy and will see what kind of efforts and which activities and resources are used for promotion and development of national tourism products. Macedonia and Serbia are neighbor countries and they offer same types of tourism as a mountain, city and religious tourism and also exchange of tourist from both countries is on a high level. Also will analyze who create and implemented tourism marketing policy in each country. In detail, will analyze the assets which are sort out for development and promotion of Macedonian and Serbian tourism products and their effect on the increasing or decreasing number of tourists. The effectiveness of tourism policy of both destinations will analyze through competitiveness index and quantitative analyze. With Travel and Tourism Competitiveness Index (TTCI) by World Economic Forum will compare the competitiveness of both countries. Also with quantitative analyze of tourism indicators will see which destination is more successful. The period that will analyze will be from 2009 to the 2015 year.
\end{abstract}

Keywords: tourism, marketing, destination, comparison, competitiveness, Macedonia, Serbia

\section{Introduction}

In the recent years, every country around the world takes many steps to increase the number of visitors in their country. To attract more visitors successfully every country as a tourist destination must apply national tourism marketing in the best way. Well planned national marketing give results and build competitiveness and image of the tourist destination.

Every tourist destination should have its created marketing strategy for tourism development. The development of the term tourist destination has its logical initial point and outcome within the term tourist place which together with their factors, created intensity and continuity of visits, thereby existential resources for the local population (Weber, Mikacic,1994, p.31).

A Sofia University St. Kliment Ohridski, Sofia, Bulgaria, e-mail: dejangalovski@gmail.com 
From a marketing point of view, a tourist destination represents something more than just a geographical location. It is an integration of information, goods, services, cultural heritage, natural resources and artificially created attractions that have the attribute to bring a lot of tourists in one location (Leiper, 1995; Bieger, 1998).

In tourism industry have many competitors and tourist destinations and all of them must follow the dynamic trend and adapt to the world tourist market and must be innovative in order to be more competitive in the market to attract more tourists.

The main goal of every tourist destination is to attract more tourists and to spend more money during their visit to the destination. The effectiveness of tourist destination policy is reflected in the number of tourist arrivals and receipts.

\section{Macedonian Tourism Product}

Macedonia disposes of with rich natural, historical, cultural and tourist goods. Macedonia is still almost intact in its unique beauty and diversity of lakes, high mountains, forests, rivers, springs and many cultural monuments and archaeological sites. Macedonia has a diversified topography, with hills, valleys, mountains, rivers, large and small lakes and spas. It is also known for its biodiversity. Almost half of its territory is agricultural land, and more than a third is covered by forests.

Tourist product of Macedonia is a rich combination of cultural and natural inheritance, which is distinguished with broadly large landscapes of lakes and mountain views. Regarding the diversity and richness of its cultural heritage and natural resources, Macedonia has nowadays a wide range of varied potentials for offering different types of tourism, which can very well combine in order to propose the substance for attractive tourist products (Marinoski, Korunovski, 2012, p.25): Cultural tourism; Lake tourism; Mountain tourism; Rural and ecotourism; City tourism; Spa tourism and Wine tourism.

\section{Macedonian Tourism Marketing Policy}

In conducting and creating the tourists policy and promotion of tourist product of Macedonia, the sector of Tourism of the Ministry of Economy and Agency for promotion and support of tourism has a main role.

The Agency (www.tourismmacedonia.gov.mk) was established on 01.12.2008 and has an aim to promote the tourism in Macedonia abroad, professionally to present all segments and region from the tourist offer with final aim development and growth of the tourism in Macedonia. The agency promotes tourism of Macedonia through: advancement and promotion of tourism; preparation and implementation of the Programme for Promotion and Support of Tourism; providing promotional material to promote tourism values; actively promoting the overall tourism potential Since 2010 from the budget are distinguished assets which the spend on realization of the program for promotion and support of tourism, total assets for each year can be seen in Table 1. 
Table 1. Assets aimed for realization of the program of the agency

\begin{tabular}{|l|c|c|c|c|c|c|}
\hline Year & 2010 & 2011 & 2012 & 2013 & 2014 & 2015 \\
\hline Total assetmkd & 9.327 .000 & 7.600 .000 & 8.047 .000 & 139.935 .000 & 231.380 .000 & 22.720 .000 \\
\hline
\end{tabular}

Source: www.tourismmacedonia.gov. $m k(1 \mathrm{mkd}=0.01612 €)$

Assets aimed for realization of the program for promotion and support of are allocated for following activities: conventional promotional activities (making and printing promotion material, presentation on international fairs, inviting international tour operators and journalist, billboard campaign, promotion in international print media, promotion of tourist potential and education through international matches, conferences, workshops which are with international meaning), activities for electronic promotion, organizing Day of Macedonian tourism in particular countries, specific promotion activity aimed to transit passengers, activities for tourism support, subsidiary of foreign organized tourist turnover and many more other activities.

The most important national branding campaigns are Macedonia Timeless and Essential Macedonia. Macedonia Timeless (www.macedonia-timeless.com) is a series of promotional tourist videos about the Republic of Macedonia. The videos showcase scenery from the Balkan country and of Macedonian culture to a foreign audience. Each video of the project is the work of a private production company, carried out on behalf of the Macedonian government, which officially funds the effort. First Group of Six Tourism Commercials is: 2 General; Macedonian Temples; Ohrid...City of Light; Macedonian Wines; Archaeology. After these commercials are made also few more commercial videos for Macedonian capital city Skopje, Macedonian Food, Adventure in Macedonia and Macedonia for couples. On the official YouTube channel of Macedonia Timeless from 27. June 2012 to a nowadays total viewing of video clips are 10.800.0oo views. On the official Facebook page of Macedonia Timeless have more than 40000 people who like the page. Essential Macedonia is documentary about Macedonia's tourist potentials and natural resources, which was broadcasted at the program of Travel Channel in duration of 30 minutes. The documentary is presented in 20 languages and 120 countries across the globe for three years.

\section{Serbian Tourism Product}

Serbia has an exceptionally favorable geographic and traffic position, numerous natural resources, long history and tradition, cultural and historical heritage, the general recognition, preserved natural resources, great human potential, diversified structure attractiveness - it could be a great tourist potential that has not been adequately exploited, bearing in mind that Serbia has not appropriately positioned as a tourist destination in the international market. Serbian tourism potentials are not far enough valorized, because tourism was never a serious issue of the development policy of the Republic of Serbia. Also the war in former Yugoslavia, economic sanctions and NATO intervention heavily affected Serbian economy and devastated tourism.

The perception of Serbia is changing and it is beginning to be perceived as a country of fun, mostly due to its vibrant nightlife, music festivals such as Exit (awarded the best music festival in Europe), the ethno-music festival in Guca and similar events which are often commented on in social media (Sekulovic, 2015, p.1631). 
As tourism products of special importance for the development of tourism are: (Strategy of tourism development of Republic of Serbia, 2016, p.28): City tourism; Events (cultural and sports events); Mountain tourism; Spa and wellness tourism (medical/balneal); Touring; Rural tourism; Nautical tourism; Business tourism + MICE; Cultural heritage; Special interest tourism and Transit tourism.

\section{Serbian Tourism Marketing Policy}

Existing organizations management of tourist destinations in the Republic of Serbia is regulated by the Law on Tourism and for that, the responsible is Ministry of Trade, Tourism and Services and for the promotion of tourist destination is responsible The National Tourism Organisation of Serbia.

In the area of tourism, the Ministry's responsibilities are (www.mtt.gov.rs) strategy and policy for tourism development; integrated planning and development of tourism and related activities; development, proclamation and sustainable use of tourist destinations; categorization of tourist sites; implementation of incentives and the provision of material and other conditions for the promotion of tourism development; promotion of tourism in the country and abroad; taxes, fees and penalties in tourism; property and legal affairs in tourism; improvement of the value and competitiveness of tourism products; tourism market research and the development of the tourist information system and many more similar activities.

The National Tourism Organisation of Serbia (www.serbia.travel/about-us) was founded in 1994 as a government organization to promote and improve tourism in the Republic of Serbia in both the domestic and foreign tourism markets, with the aim of affirming the value and potential of the country's tourist industry. TOS is the legal successor of the former Tourist Association of Serbia.

In order to implement tourism information and marketing activities in an original way, to ensure that Serbia is included on European travel itineraries and to consolidate bilateral cooperation in the field of tourism development, TOS attends all large international tourism fairs and cooperates with other national tourism organisations, as well as with other international, regional and professional tourism associations.

Two of the most popular and successful marketing campaigns of Serbia as tourist destinations are LifeStyle Serbia and Soulfood Serbia.

Lifestyle Serbia is a campaign created by National Tourism Organisation of Serbia, targeting and promoting youth in Serbia in 2014 year. The goal of the campaign is to include as many people as possible, who will share their own lifestyle in Serbia. Two weeks since the campaign started, Instagram users already uploaded more than 1000 photos of their favorite places and activities in Serbia.

Soulfood Serbia is the name of a marketing campaign by Tourist Organization of Serbia for 2012 which the main theme was the gastronomy as an important part of the tourism offer of Serbia. This campaign promotes authentic gastronomic products of Serbia, with special emphasis on those who are or should be labeled as a protected geographical origin.

On the official Youtube channel of the National Tourism Organisation of Serbia where can watch promotional videos of these two campaigns and other promotional tourist videos of Serbia as tourist destination form January 2006 till the end of 2015 year has a total of around 3.00o.ooo views. Official Facebook page of National Tourism Organisation of Serbia has 23.000 likes and official Instagram profile has 17.000 followers. 


\section{Travel and Tourism Competitiveness Index}

Currently, TTCI index is published every two years and reveals the competitive advantages and disadvantages of tourism in the observed countries. This index is the only model that is now in practice used to measure competitiveness, and as such represents a solid basis for a comparison between the competitiveness of many countries in the world. In the following tables, will see the rank of competitiveness of the Republic of Macedonia and Serbia from 2009 to 2015 year.

Table 2. TTCl index of competitiveness of Macedonia from 2009 to 2013

\begin{tabular}{|c|c|c|c|c|c|c|}
\hline \multirow{2}{*}{$\begin{array}{l}\text { Year } \\
\text { TTCI }\end{array}$} & \multicolumn{2}{|c|}{2009} & \multicolumn{2}{|c|}{2011} & \multicolumn{2}{|c|}{2013} \\
\hline & $\begin{array}{c}\text { Rank } \\
\text { (out of 133) }\end{array}$ & $\begin{array}{c}\text { Score } \\
\text { (1-7 scale) }\end{array}$ & $\begin{array}{c}\text { Rank } \\
\text { (out of 139) }\end{array}$ & $\begin{array}{c}\text { Score } \\
\text { (1-7 scale) }\end{array}$ & $\begin{array}{c}\text { Rank } \\
\text { (out of } 140 \text { ) }\end{array}$ & $\begin{array}{c}\text { Score } \\
\text { (1-7 scale) }\end{array}$ \\
\hline Overall index & 80 & 3.8 & 76 & 4.0 & 75 & 4.0 \\
\hline T\&T regulation framework & 69 & 4.5 & 56 & 4.8 & 57 & 4.8 \\
\hline Policy rules and regulations & 76 & 4.3 & 78 & 4.3 & 66 & 4.5 \\
\hline Environmental sustainability & 83 & 4.3 & 65 & 4.6 & 73 & 4.5 \\
\hline Safety and security & 64 & 5.2 & 42 & 5.4 & 43 & 5.3 \\
\hline Health and hygiene & 42 & 5.6 & 42 & 5.6 & 47 & 5.7 \\
\hline Prioritization of Travel\&Tourism & 129 & 2.9 & 106 & 4.0 & 99 & 4.0 \\
\hline T\&T business env. And infrast. & 75 & 3.3 & 78 & 3.5 & 74 & 3.6 \\
\hline Air transport infrastructure & 119 & 2.1 & 127 & 2.1 & 122 & 2.2 \\
\hline Ground transport infrastructure & 76 & 3.2 & 88 & 3.2 & 84 & 3.2 \\
\hline Tourism infrastructure & 63 & 3.4 & 69 & 3.8 & 64 & 4.3 \\
\hline ICT infrastructure & 67 & 2.9 & 55 & 3.5 & 60 & 3.4 \\
\hline Price compet. in the T\&T industry & 59 & 4.8 & 49 & 4.8 & 46 & 4.8 \\
\hline T\&T hum. cul. nat. resources & 87 & 3.7 & 93 & 3.6 & 100 & 3.6 \\
\hline Human resources & 70 & 5.0 & 75 & 4.8 & 81 & 4.8 \\
\hline Education and training & 75 & 4.6 & 92 & 4.3 & 97 & 4.3 \\
\hline Availability of qualified labor & 61 & 5.5 & 30 & 5.3 & 37 & 5.2 \\
\hline Affinity for Travel \& Tourism & 69 & 4.7 & 53 & 4.8 & 73 & 4.6 \\
\hline Natural resources & 92 & 2.8 & 92 & 2.7 & 113 & 2.8 \\
\hline Cultural resources & 70 & 2.2 & 74 & 2.2 & 75 & 2.2 \\
\hline
\end{tabular}

Source : The Travel \& Tourism Competitiveness Report, 2009/2011/2013

In Table 2 can see that the value of the index of competitiveness of travel and tourism of the Republic of Macedonia, in the reporting period grow slowly. In general best ratings have in subindex T\&T regulation framework and the weakest ratings in subindex T\&T business environment and infrastructure. The best rank the Republic of Macedonia had in 2013 at position 75 of 140 countries and the best score received for access to Health and hygiene and Safety and security, then for Availability of qualified labor and Price competitiveness in the T\&T industry, and the worst for access to Air transport infrastructure and Cultural resources. The big increase can notice for access Prioritization of Travel \& Tourism, when the score in 2009 was 2.9 , in 2011 and 2013 was 4.0 on a scale from 1 to 7 . 
Table 3. TTCI index of competitiveness of Serbia from 2009 to 2013

\begin{tabular}{|c|c|c|c|c|c|c|}
\hline \multirow{2}{*}{$\begin{array}{l}\text { Year } \\
\text { TTCI }\end{array}$} & \multicolumn{2}{|c|}{2009} & \multicolumn{2}{|c|}{2011} & \multicolumn{2}{|c|}{2013} \\
\hline & $\begin{array}{c}\text { Rank } \\
\text { (out of 133) }\end{array}$ & $\begin{array}{c}\text { Score } \\
\text { (1-7 scale) }\end{array}$ & $\begin{array}{c}\text { Rank } \\
\text { (out of 139) }\end{array}$ & $\begin{array}{c}\text { Score } \\
\text { (1-7 scale) }\end{array}$ & $\begin{array}{c}\text { Rank } \\
\text { (out of } 140 \text { ) }\end{array}$ & $\begin{array}{c}\text { Score } \\
\text { (1-7 scale) }\end{array}$ \\
\hline Overall index & 88 & 3.7 & 82 & 3.9 & 89 & 3.8 \\
\hline T\&T regulation framework & 78 & 4.4 & 67 & 4.6 & 74 & 4.5 \\
\hline Policy rules and regulations & 67 & 4.4 & 68 & 4.4 & 103 & 4.1 \\
\hline Environmental sustainability & 127 & 3.6 & 124 & 4.0 & 115 & 4.1 \\
\hline Safety and security & 85 & 4.8 & 66 & 4.9 & 55 & 5.0 \\
\hline Health and hygiene & 44 & 5.6 & 41 & 5.6 & 46 & 5.7 \\
\hline Prioritization of Travel\&Tourism & 119 & 3.3 & 105 & 4.0 & 108 & 3.6 \\
\hline T\&T business env. and infrast. & 80 & 3.2 & 84 & 3.4 & 81 & 3.4 \\
\hline Air transport infrastructure & 105 & 2.4 & 111 & 2.3 & 110 & 2.3 \\
\hline Ground transport infrastructure & 91 & 2.9 & 115 & 2.8 & 117 & 2.8 \\
\hline Tourism infrastructure & 58 & 3.5 & 49 & 4.5 & 56 & 4.5 \\
\hline ICT infrastructure & 63 & 2.9 & 62 & 3.3 & 49 & 3.6 \\
\hline Price compet. in the T\&T industry & 90 & 4.3 & 118 & 4.0 & 119 & 3.8 \\
\hline T\&T hum. cul. nat. resources & 96 & 3.6 & 94 & 3.6 & 109 & 3.4 \\
\hline Human resources & 54 & 5.2 & 76 & 4.8 & 94 & 4.6 \\
\hline Education and training & 66 & 4.7 & 82 & 4.5 & 95 & 4.3 \\
\hline Availability of qualified labor & 31 & 5.7 & 57 & 5.1 & 80 & 5.0 \\
\hline Affinity for Travel \& Tourism & 83 & 4.6 & 66 & 4.6 & 104 & 4.3 \\
\hline Natural resources & 126 & 2.1 & 123 & 2.2 & 131 & 2.4 \\
\hline Cultural resources & 64 & 2.4 & 59 & 2.7 & 65 & 2.5 \\
\hline
\end{tabular}

Source: The Travel \& Tourism Competitiveness Report, 2009/2011/2013

In Table 3 can see that the value of the index of competitiveness of travel and tourism of Serbia, during the reporting period varied from year to year. In general best ratings have in subindex T\&T regulation framework and the weakest ratings in subindex T\&T human, cultural and natural resources. The best rank Serbia had in 2011 at position 82 of 139 countries and the best score received for access to Health and hygiene and Safety and security, then for Availability of qualified labor and Human resources, and the worst for access to Air transport infrastructure and Natural resources. The big increase can notice for access Tourism infrastructure when the score in 2009 was 3.5, in 2011 and 2013 was 4.5 on the scale from 1 to 7.

Table 4. Competitiveness of the Republic of Macedonia and Serbia for 2015

\begin{tabular}{|l|c|c|c|c|}
\hline \multirow{2}{*}{ TTCI } & \multicolumn{2}{|c|}{ Macedonia } & \multicolumn{2}{c|}{ Serbia } \\
\cline { 2 - 5 } & Rank (out of 141) & Score (1-7 scale) & Rank (out of 141) & Score (1-7 scale) \\
\hline Overall index & 82 & 3.50 & 95 & 3.34 \\
\hline Enabling Environment & 49 & 5.11 & 67 & 4.72 \\
\hline Business Environment & 34 & 4.87 & 133 & 3.38 \\
\hline Safety and security & 45 & 5.75 & 59 & 5.46 \\
\hline Health and hygiene & 42 & 5.99 & 38 & 6.04 \\
\hline Human Res. and Labor Market & 73 & 4.47 & 89 & 4.29 \\
\hline
\end{tabular}




\begin{tabular}{|l|c|c|c|c|}
\hline \multirow{2}{*}{ TTCI } & \multicolumn{2}{|c|}{ Macedonia } & \multicolumn{2}{c|}{ Serbia } \\
\cline { 2 - 5 } & Rank (out of 141) & Score (1-7 scale) & Rank (out of 141) & Score (1-7 scale) \\
\hline ICT Readiness & 55 & 4.47 & 56 & 4.45 \\
\hline T\&T Policy and Enabling Conditions & 110 & 3.74 & 113 & 3.71 \\
\hline Prioritization of Travel\&Tourism & 81 & 4.41 & 113 & 3.83 \\
\hline International Openness & 104 & 2.36 & 101 & 2.39 \\
\hline Price Competitiveness & 79 & 4.55 & 78 & 4.56 \\
\hline Environmental Sustainability & 107 & 3.65 & 72 & 4.08 \\
\hline Infrastructure & 74 & 3.41 & 102 & 3.19 \\
\hline Air Transport Infrastructure & 85 & 2.39 & 98 & 2.13 \\
\hline Ground and Port Infrastructure & 81 & 3.25 & 63 & 2.95 \\
\hline Tourist Service Infrastructure & 59 & 4.58 & 122 & 4.50 \\
\hline Natural and Cultural Resources & 125 & 1.72 & 135 & 1.75 \\
\hline Natural resources & 121 & 2.15 & 67 & 1.90 \\
\hline Cultural res. and Business Travel & 110 & 1.30 & & 1.61 \\
\hline
\end{tabular}

Source: The Travel \& Tourism Competitiveness Report, 2015

In Table 4 can see the value of the index of competitiveness of travel and tourism of the Republic of Macedonia and Serbia for 2015 year.

The Republic of Macedonia for 2015 by TTCI index is ranking at 82 positions of 141 countries and has best ratings in subindex Enabling Environment and the weakest ratings in subindex Natural and Cultural Resources. The best score received for access to Health and hygiene and Safety and security, then for Business Environment and Tourist Service Infrastructure, and the worst for access Cultural resources and Business Travel and Natural resources.

Serbia for 2015 by TTCI index is ranking at 95 positions of 141 countries and has best ratings in subindex Enabling Environment and the weakest ratings in subindex Natural and Cultural Resources. The best score received for access to Health and hygiene and Safety and security, then for Price Competitiveness and Tourist Service Infrastructure, and the worst for access Cultural resources and Business Travel and Natural resources.

According to the paragraph of the World Economic Forum countries that had achieved the rank above 5oth place can be considered globally competitive tourist destinations. In this case, both countries had rank below 50 and they are not globally competitive tourist destinations. The Republic of Macedonia has better score and rank in compare with Serbia but the difference is not much significant between these countries.

\section{Quantitative Analysis of Tourism Indicators}

In the following tables will make an analysis of quantitative indicators like a population, a number of arrivals of international tourists, receipts of international tourism of tourist destination of Macedonia and Serbia for the period from 2009 to 2015 year. This analysis will find out how big is a share of tourism arrivals and receipts of these tourist destinations in the world tourism and will find out the share of international arrivals of tourists in regards of a number of population of these tourist destinations. Also will analyze index of this indicators in regards to previous years, how is the trend of international tourist arrivals and receipts every year. 
Table 5. Quantitative indicator of tourist destination the Republic of Macedonia

\begin{tabular}{|c|c|c|c|c|c|c|c|}
\hline Indicator / Year & 2009 & 2010 & 2011 & 2012 & 2013 & 2014 & 2015 \\
\hline Population, total & 2058920 & 2062443 & 2065888 & 2069270 & 2072543 & 2075625 & 2078453 \\
\hline $\begin{array}{l}\text { International tourism, number of } \\
\text { arrivals }\end{array}$ & 259000 & 262000 & 327000 & 351000 & 400000 & 425000 & 486000 \\
\hline $\begin{array}{l}\text { International tourism, receipts (current } \\
\text { millions US\$) }\end{array}$ & 232 & 199 & 242 & 237 & 270 & 298 & 270 \\
\hline $\begin{array}{l}\text { Share of international number of } \\
\text { arrivals/population (\%) }\end{array}$ & 12.6 & 12.7 & 15.8 & 17.0 & 19.3 & 20.5 & 23.4 \\
\hline Share of inter. arrivals/world (\%) & 0.028 & 0.027 & 0.032 & 0.033 & 0.036 & 0.037 & 0.040 \\
\hline Share of inter. receipts/world (\%) & 0.023 & 0.018 & 0.019 & 0.018 & 0.019 & 0.021 & 0.019 \\
\hline $\begin{array}{l}\text { World international tourism, number } \\
\text { of arrivals in million }\end{array}$ & 907.9 & 967.2 & $1,008.5$ & $1,059.7$ & $1,110.8$ & $1,160.9$ & $1,200.1$ \\
\hline $\begin{array}{l}\text { World international tourism, receipts } \\
\text { (current US\$) in bilion }\end{array}$ & $1,012.6$ & $1,104.6$ & $1,237.3$ & $1,281.9$ & 1,369.9 & $1,434.0$ & $1,437.0$ \\
\hline $\begin{array}{l}\text { International tourism arrivals in } \\
\text { regards to previous year (\%) }\end{array}$ & 1.6 & 1.2 & 24.8 & 7.3 & 14.0 & 6.2 & 14.3 \\
\hline $\begin{array}{l}\text { World intern. tourism arrivals in } \\
\text { regards to previous year (\%) }\end{array}$ & -4.2 & 6.5 & 4.3 & 5.1 & 4.9 & 4.5 & 3.4 \\
\hline $\begin{array}{l}\text { International tourism receipts in } \\
\text { regards to previous year (\%) }\end{array}$ & -11.4 & -14.2 & 21.6 & -2.1 & 13.9 & 10.4 & -9.4 \\
\hline $\begin{array}{l}\text { World inter. tourism receipts in regards } \\
\text { to previous year (\%) }\end{array}$ & -9.9 & 9.2 & 12.0 & 3.6 & 6.9 & 4.7 & 0.2 \\
\hline
\end{tabular}

Source: data.worldbank.org

Table 6. Quantitative indicator of tourist destination Serbia

\begin{tabular}{|c|c|c|c|c|c|c|c|}
\hline Indicator / Year & 2009 & 2010 & 2011 & 2012 & 2013 & 2014 & 2015 \\
\hline Population, total & 7320807 & 7291436 & 7234099 & 7199077 & 7164132 & 7130576 & 7098247 \\
\hline $\begin{array}{l}\text { International tourism, number of } \\
\text { arrivals }\end{array}$ & 645000 & 683000 & 764000 & 810000 & 922000 & 1029000 & 1132000 \\
\hline $\begin{array}{l}\text { International tourism, receipts (current } \\
\text { millions US\$) }\end{array}$ & 986 & 950 & 1149 & 1080 & 1221 & 1352 & 1322 \\
\hline $\begin{array}{l}\text { Share of international number of } \\
\text { arrivals/population (\%) }\end{array}$ & 8.8 & 9.4 & 10.6 & 11.2 & 12.9 & 14.4 & 15.9 \\
\hline Share of inter. arrivals/world (\%) & 0.071 & 0.071 & 0.076 & 0.076 & 0.083 & 0.089 & 0.094 \\
\hline Share of inter. receipts/world (\%) & 0.097 & 0.086 & 0.093 & 0.084 & 0.089 & 0.094 & 0.092 \\
\hline $\begin{array}{l}\text { World international tourism, number } \\
\text { of arrivals in million }\end{array}$ & 907.9 & 967.2 & $1,008.5$ & $1,059.7$ & $1,110.8$ & $1,160.9$ & $1,200.1$ \\
\hline $\begin{array}{l}\text { World international tourism, receipts } \\
\text { (current US\$) in bilion }\end{array}$ & $1,012.6$ & $1,104.6$ & $1,237.3$ & 1,281.9 & 1,369.9 & $1,434.0$ & $1,437.0$ \\
\hline $\begin{array}{l}\text { International tourism arrivals in } \\
\text { regards to previous year (\%) }\end{array}$ & -0.1 & 5.9 & 11.9 & 6.0 & 13.8 & 11.6 & 10.1 \\
\hline $\begin{array}{l}\text { World intern. tourism arrivals in } \\
\text { regards to previous year (\%) }\end{array}$ & -4.2 & 6.5 & 4.3 & 5.1 & 4.9 & 4.5 & 3.4 \\
\hline $\begin{array}{l}\text { International tourism receipts in } \\
\text { regards to previous year (\%) }\end{array}$ & -11.5 & -3.6 & 20.9 & -6.0 & 13.1 & 10.7 & -2.2 \\
\hline $\begin{array}{l}\text { World inter.tourism receipts in regards } \\
\text { to previous year (\%) }\end{array}$ & -9.9 & 9.2 & 12.0 & 3.6 & 6.9 & 4.7 & 0.2 \\
\hline
\end{tabular}

Source: data.worldbank.org 
In table 5 can see the quantitative indicators of tourism for the period of 2009 to 2015 of the Republic of Macedonia as a tourist destination. It can be noticed that the biggest share of international tourist arrivals in the Republic of Macedonia had in 2015 with $23.4 \%$ of total population of the country. The biggest increase in international tourist arrivals had in 2011 for $24.8 \%$ in regard to previous years. The biggest increase in international tourism receipts had in 2011 for $21.6 \%$, and falls of international tourism receipts had in 2010 for $-14.2 \%$, in 2009 for $-11.4 \%$ and in 2015 for $-9.4 \%$ in regard to previous years. In the Republic of Macedonia, the biggest number of international tourist arrivals had in 2015 year and in 2014 had the biggest international tourism receipts.

In table 6 can see the quantitative indicators of tourism for the period of 2009 to 2015 of Serbia as a tourist destination. It can be noticed that the biggest share of international tourist arrivals in Serbia had in 2015 with $15.9 \%$ of total population of the country. The biggest increase in international tourist arrivals had in 2013 year for $13.8 \%$, in regard to previous years, and the fall had in 2009 for $-0.1 \%$ in regard to previous years. The biggest increase in international tourism receipts had in 2011 for $20.9 \%$ and the falls of international tourism receipts had in 2009 for $-11.5 \%$, in 2012 for $-6 \%$, in 2010 for $-3.6 \%$ and then in 2015 for $-2.2 \%$ in regard to previous years. In Serbia, the biggest number of international tourist arrivals had in 2015 year and in 2014 year had the biggest international tourism receipts.

By comparing Macedonia and Serbia on the international tourism market by the quantitative tourism indicators for the period 2009-2015, in Table 5 and 6 could draw the following conclusions. Macedonia and Serbia have an increase of the international number of arrivals every year but the international number of arrivals don't exceed the number of population, this means that both countries are in the development stage of tourism. The highest share of the international number of arrivals in regards to a population of both countries are in 2015 year, but Macedonia has a bigger share of the international number of arrivals in regards to the population in comparison to Serbia. Also can see that both countries have rise and fall of international receipts in same years, but Macedonia have the least share of international receipts of total world international receipts by tourism. For example, in 2015 year the international receipts by tourism in Macedonia were 270 million US\$, and in Serbia were 1.3 billion US\$. When it comes to earnings from tourism can conclude that Macedonia can't be competitive in regards to Serbia, because international receipts by tourism of Macedonia is modest in comparison to Serbia.

\section{Conclusion}

Macedonia and Serbia are neighbor's countries and they have many similar things like a culture, history and one time period from 1945 to 1991 year both countries were members of the Socialist Federal Republic of Yugoslavia. They have a lot of similarities and few differences in their tourist products, both countries have rich nature, history and culture, and each of them has some specifics and unique attractions.

Tourism in Macedonia and Serbia is on developing level and in last few years is made efforts to promote and develop tourist product. Both countries do not have access to the sea and offer similar tourist products like lake tourism, religious tourism, because both countries are Orthodox countries and have many important and unique religious churches and monasteries, mountain tourism and gastronomic tourism. Also, tourism marketing policy and institutions responsible for the promotion of national tourism of both countries is similar. 
It can be notices that by TTCI by World Economy Forum Macedonia have a better rank than Serbia, but in the overall score and in most of the sub indexes they achieve similar results.

From 2009 to 2015 year, every year both countries have an increase in tourist arrivals of the foreign tourist and in the same years in that period have fall in international tourism receipts in regards to the previous year. But also can conclude that international receipts by tourism of Macedonia are modest in comparison with Serbia.

Also can conclude that efforts by government institutions responsible for promotion and developing of tourism of each country from period from 2009 to 2015 year have positive results because both countries have increase of number of international tourist arrivals and receipts, but with some few falls in international tourist receipts.

\section{References}

Bieger, T. 1998. Reengineering destination marketing organizations - the case of Switzerland. Tourist Review 53(3), 4-17.

Leiper, N. 1995. Tourism Management, Melbourne: RMIT Press

Marinoski, N. Korunovski, S. 2012. Tourism in Macedonia in changing environment. Procedia - Social and Behavioral Sciences 44, 19-31.

Sekulovic, N., 2015. Trends and New Initiatives in Tourism at the Time of the General Economic Crisis and the Current Situation in Serbian Tourism. Procedia Economics and Finance 23, 1628-1634.

Weber, S., Mikačić, V., 1994. Osnove turizma. Školska knjiga, Zagreb.

\section{|| || ||}

Internet 1: Strategy of tourism development of Republic of Serbia for the period 2016-2025 Retrieved February 2018 from http://mtt.gov.rs/download/3/strategija.pdf

Internet 2: The Travel \& Tourism Competitiveness Report 2009, World Economic Forum, Geneva Retrieved May, 2017, from: http://www3.weforum.org/docs/WEF_GCR_TravelTourism_Report_2009.pdf

Internet 3: The Travel \& Tourism Competitiveness Report 2011, World Economic Forum, Geneva Retrieved May, 2017, from: http://www3.weforum.org/docs/WEF_TravelTourismCompetitiveness_Report_2011.pdf

Internet 4: The Travel \& Tourism Competitiveness Report 2013, World Economic Forum, Geneva Retrieved May, 2017, from: http://www3.weforum.org/docs/WEF_TT_Competitiveness_Report_2013.pdf

Internet 5: The Travel \& Tourism Competitiveness Report 2015, World Economic Forum, Geneva Retrieved May, 2017, from: http://www3.weforum.org/docs/TT15/WEF_Global_Travel\&Tourism_Report_2015.pdf

Internet 6: www.data.worldbank.org

Internet 7: www.mtt.gov.rs

Internet 8: www.serbia.travel

Internet 9: www.tourismmacedonia.gov.mk 